\title{
Acronyms and symbols ${ }^{1}$
}

\begin{tabular}{|c|c|}
\hline$\alpha$ & constant term in a Fama UIP equation \\
\hline & coefficient of the home output gap in a Taylor Rule equation \\
\hline & $\begin{array}{l}\text { coefficient of the foreign output gap in a Taylor Rule } \\
\text { equation }\end{array}$ \\
\hline & coefficient of the inflation terms in a Taylor Rule equation \\
\hline & $\begin{array}{l}\text { coefficient of the foreign inflation terms in a Taylor Rule } \\
\text { equation }\end{array}$ \\
\hline$\beta$ & $\begin{array}{l}\text { Fama's beta coefficient, i.e., the coefficient of the lagged } \\
\text { interest rate differential in a Fama equation }\end{array}$ \\
\hline B & $\begin{array}{l}(1-\beta) \text { the coefficient of ID }(t) \text { in the expression for the } \\
\text { excess return from going long on dollars, } \mathrm{ER}_{\$}\end{array}$ \\
\hline$\beta^{\prime}$ & $\begin{array}{l}(\beta-1) \text { the coefficient of } \operatorname{ID}(t) \text { in the expression for the } \\
\text { excess return from going long on } f x, E_{f x}\end{array}$ \\
\hline$\beta 1$ & $\begin{array}{l}\text { coefficient of the forward premium (FP) in a smooth } \\
\text { transition nonlinear UIP econometric model }\end{array}$ \\
\hline$\beta 2$ & $\begin{array}{l}\text { coefficient of the }[\mathrm{FP} \times \mathrm{G}] \text { term in a smooth transition } \\
\text { nonlinear UIP econometric model }\end{array}$ \\
\hline$\beta_{\text {I }}$ & the beta coefficient in the inactive zone of the fx market \\
\hline & the beta coefficient in the active zone of the fx market \\
\hline B & $\begin{array}{l}\text { Fama's } \beta \text { in Synthesis Model I if the effects of a variable } \\
\text { "risk premium" and a variable ds* term are zero }\end{array}$ \\
\hline $\mathrm{B} \& \mathrm{vW}$ & Bacchetta and van Wincoop \\
\hline CAPM & capital asset pricing model \\
\hline & covered interest parity \\
\hline & Deutsch Mark \\
\hline
\end{tabular}

1 In general: (a) any symbol, $\mathrm{Z}$, relates to the actual value of $\mathrm{Z}$ in the home country, the USA; (b) $Z^{*}$ refers to the subjectively anticipated value for $Z$; (c) $E[Z]$ is the true expected value for $Z$; and (d) $Z^{\prime}$ is the actual value of $Z$ in the foreign country. 
e random term in the equation for the fundamentals determining ID

$\epsilon \quad$ exchange rate prediction error

$\mathrm{E}[\mathrm{e} \quad$ expected value operator

$\mathrm{E}^{*}[\mathrm{]} \quad$ subjectively anticipated value operator

$\mathrm{ER}_{\$} \quad$ ex post excess return from going long on dollars

$\mathrm{ER}_{\mathrm{fx}} \quad$ ex post excess return from going long on $\mathrm{fx}$, which equals $\left(-\mathrm{ER}_{\$}\right)$

$\mathrm{ER}^{*} \quad$ ex ante excess return from going long on dollars

$\mathrm{ER}_{\mathrm{fx}} \quad$ ex ante excess return from going long on $\mathrm{fx}$

$\phi(\mathrm{t}+\mathrm{k}) \quad$ actual rate of decay in a nonzero ID from period $\mathrm{t}+\mathrm{k}-1$ to period $\mathrm{t}+\mathrm{k}$

$\phi^{*}(\mathrm{t}) \quad$ subjectively anticipated (as of period $\mathrm{t}$ ) rate of decay for a nonzero ID

$\Phi \quad$ true expected value for the rate of decay in ID

$\mathrm{f} \quad \log$ of the forward exchange rate

FP forward premium, $\mathrm{f}-\mathrm{s}$

fx foreign exchange

$\mathrm{G}$ transition function that determines the degree of reversion of deviations from UIP toward zero

$\gamma \quad$ coefficient that relates ds* to the interest rate differential

G\&T Gourinchas and Tornell

$\Gamma$

speculators' demand or supply for fx curve

$\eta_{\mathrm{s}} \quad$ home short-run price elasticity of demand for imports (defined to be positive)

$\eta_{\mathrm{L}} \quad$ home long-run price elasticity of demand for imports (defined to be positive)

$\eta_{\mathrm{s}}^{\prime} \quad$ foreign short-run price elasticity of demand for home exports (defined to be positive)

$\eta_{L}^{\prime} \quad$ foreign long-run price elasticity of demand for home exports (defined to be positive)

i home nominal interest rate

i' foreign nominal interest rate

ID home minus foreign nominal interest rate differential

ID* subjectively anticipated future interest rate differential

ID average interest rate differential

$\overline{\mathrm{ID}}_{\mathrm{ST}} \quad$ short-term interest rate differential 
ID $_{\text {LT }} \quad$ long-term interest rate differential

$\mathrm{J} \quad$ home balance of trade in $\mathrm{fx}$ units

J1 coefficient of $s(t)$ in the J function; this equals $\eta_{s}+\eta_{s}^{\prime}<0$

J2 coefficient of $s(t-k)$ in the $J$ function; this equals $\eta_{L}+\eta_{L}^{\prime}>0$

M-L Marshall-Lerner Condition

M\&P Molodtsova and Papell

$\mu \quad$ exchange rate multiplier

$\mathrm{n}(\mathrm{t}+\mathrm{k}) \quad$ optimum speculative time horizon for carry-trade in period $\mathrm{t}+\mathrm{k}$

$\Pi \quad$ profit from going long on dollar assets, except in section 2.8

$\Pi^{*} \quad$ subjectively anticipated profit from going long on dollar assets

$\Pi \quad$ desired home inflation rate in a Taylor Rule equation in section 2.8

$\Pi^{\prime}$ desired foreign inflation rate in a Taylor Rule equation

$\pi \quad$ actual home (USA) inflation rate

$\pi^{\prime} \quad$ actual foreign inflation rate

$\mathrm{p} \quad \log$ of the home price index

p' $\quad \log$ of the foreign price index

Pr probability of being in Regime 2 of the fx market

$\theta \quad$ weight given to the long-run value for the spot rate in a regressive expectations equation

$\mathbf{r}$ desired long-run value for the home real rate of interest in a Taylor Rule equation

$\mathbf{r}^{\prime} \quad$ desired long-run value for the foreign real rate of interest in a Taylor Rule equation

$\mathrm{RE} \quad$ rational expectations

$\rho \quad$ threshold magnitude or "risk premium"

$\rho^{*} \quad$ subjectively anticipated value for the "risk premium", $E^{*}[\rho]$

po exogenous component of the "risk premium"

$\rho^{\$} \quad$ implicit return from the safe-haven aspect of the dollar

$\rho^{\mathrm{D}} \quad$ default risk premium

$\rho^{\prime} \quad$ coefficient that relates the "risk premium" to the interest rate differential

S bilateral nominal exchange rate in $\$$ per unit of $\mathrm{fx}$

S $\quad \log$ of $\mathrm{S}$

$\mathrm{s}^{*} \mathrm{o} \quad \log$ of the subjectively anticipated exogenous long-run

equilibrium value for the exchange rate 
$\mathrm{s}^{*}(\mathrm{t}) \quad \log$ of the subjectively anticipated (as of period $\mathrm{t}$ ) value for the spot rate $\mathrm{n}(\mathrm{t})$ periods forward

$\tau$ random component of the actual rate of decay, i.e., $\phi=\Phi+\tau$

UIP uncovered interest parity

$\mathrm{u}(\mathrm{t}+\mathrm{k}) \quad$ forecast error when using regressive expectations

$\mathrm{V}$ the percentage change in: the spot rate, or the excess return from going long on $\mathrm{fx}$, or the nominal money supply

$\mathrm{v}(\mathrm{t}) \quad$ random component of ID in Gourinchas and Tornell (2004)

$\mathrm{W}_{\mathrm{I}} \quad$ weight given to $\beta_{\mathrm{I}}$ when calculating Fama's $\beta$

$\mathrm{W}_{\mathrm{A}} \quad$ weight given to $\beta_{\mathrm{A}}$ when calculating Fama's $\beta$

$\Omega \quad$ true expected value for cumulative net interest from carry-trade over the optimum speculative time horizon

$\Omega * \quad$ subjectively anticipated value for cumulative net interest from carry-trade over the optimum speculative time horizon

$\mathrm{X} \quad$ vector of missing variables in a Fama equation

$\mathrm{Y}(\mathrm{t}) \quad \mathrm{s}(\mathrm{t}-1)$ for extrapolative expectations; $\mathrm{E}^{*}[\mathrm{~s}(\mathrm{t})]$ as of period $\mathrm{t}-1$ for adaptive expectations; $\mathrm{s}^{*} \mathrm{o}$ in regressive expectations

$\mathrm{y}(\mathrm{t}) \quad$ home output gap in a Taylor Rule equation

$y^{\prime}(t) \quad$ foreign output gap in a Taylor Rule equation

$\Psi \quad$ number of speculators who believe that the euro will either appreciate or depreciate

$\mathrm{z}$ fundamentals that determine ID in Gourinchas and Tornell (2004)

$\mathrm{Z} \quad$ anticipated cumulative "risk premium" over the optimum speculative time horizon 